\title{
DISTRIBUTION OF THE MILLIPED GENUS APHELORIA CHAMBERLIN, 1921; SUMMARIES OF PERIPHERAL LOCALITIES AND ONES OF A. VIRGINIENSIS (DRURY, 1770) WEST OF THE MISSISSIPPI RIVER (POLYDESMIDA: XYSTODESMIDAE)
}

\author{
Rowland M. Shelley ${ }^{1}$ and Chris T. McAllister ${ }^{2}$
}

\begin{abstract}
The milliped genus Apheloria occupies a broad area in Québec and Ontario, Canada, and the United States east of the Central Plains, lying generally north of the Gulf Coastal states. It is reported for the 1st time from New Jersey, District of Columbia, Illinois, and Kansas; and the 1st localities are recorded for Massachusetts, Connecticut, South Carolina, Georgia, Alabama, and Wisconsin. The projected distribution encompasses all or parts of the District of Columbia and 27 states, including Vermont and Delaware, where the genus has not been taken; New Hampshire and Mississippi lie outside the range. Chesapeake Bay and the Connecticut River form apparent eastern boundaries in Maryland-Virginia and New England, respectively; the Tennessee River does likewise on the south in northern Alabama. Aside from Arkansas, comparatively few records exist from the 6 projected states of occurrence west of the Mississippi River. Only 1 each is available from Iowa and Kansas, and there are no definite localities in Nebraska, where occurrence is postulated at Omaha, the type locality of Fontaria luminosa Kenyon, 1893. Confirmation with fresh material is necessary, but this name seems referrable to Apheloria and may be senior to either A. virginiensis iowa or A. v. reducta, both by Chamberlin, 1939, if 2 distinct races occur west of the Mississippi River.
\end{abstract}

Key words: Apheloria, Apheloria virginiensis, Apheloria virginiensis reducta, Apheloria virginiensis iowa, Fontaria luminosa, Mississippi River.

The xystodesmid milliped genus Apheloria Chamberlin, 1921, is the 2nd-most widely ranging North American genus in the family (after Pleuroloma Rafinesque, 1820) and the 5 th overall among North American diplopods (after Oriulus Chamberlin, 1940 [Julida: Parajulidae]; Narceus Rafinesque, 1820 [Spirobolida: Spirobolidae]; Pleuroloma; and Scytonotus C.L. Koch, 1847 [Polydesmida: Polydesmidae]) (Keeton 1960, Shelley 1980, 1993, 2002, Shelley et al. 2004, 2005, 2006). It occupies a broad area between the Central Plains and the Atlantic Ocean that lies generally north of the Gulf Coastal states and extends northward into southern Québec, eastward into western New England, and southward to the southern extremity of the Ouachita Physiographic Province in Oklahoma (Fig. 1; Causey 1954, Shelley 1988, 2002, Snider 1991, Hoffman 1999, McAllister et al. 2002, 2003; plus unpublished records in the ensuing repositories and records cited on the INHS web page [acronyms below]). Apheloria is 1 of only 2 unrevised xystodesmid genera in eastern North America, the other being
Nannaria Chamberlin, 1918; however, both were addressed synoptically by Hoffman (1999). According to this treatment, Apheloria comprises 3 species: A. virginiensis (Drury, 1770), which is divided into 5 subspecies and occurs throughout the generic range except for the southeast; A. montana (Bollman, 1887), in the southern Applachian Mountains and Cumberland Plateau from Kentucky and Virginia to Georgia and Alabama; and A. tigana Chamberlin, 1939, extending from the Blue Ridge Province in southern Virginia to southeastern North Carolina. The species of Apheloria are colorful, relatively large-bodied xystodesmids with primarily yellow paranota and either yellow to pinkish transverse bands along the caudal metatergal margins, or discrete, yellow middorsal spots or semilunar splotches (Shelley 1978: figs. 62-63; Whitehead and Shelley 1992: figs. 2-3); a color photo of $A$. montana, with yellow middorsal spots, from Oak Ridge, Anderson Co., Tennessee, adorns the cover of the March 1967 (vol. 17[3]) issue of Bioscience. As sympatric xystodesmids display the same or

\footnotetext{
${ }^{1}$ Research Laboratory, North Carolina State Museum of Natural Sciences, 4301 Reedy Creek Road, Raleigh, NC 27607. E-mail: rowland.shelley@ ncmail.net

${ }^{2}$ Department of Physical and Life Sciences, Chadron State College, 1000 Main St., Chadron, NE 69337.
} 


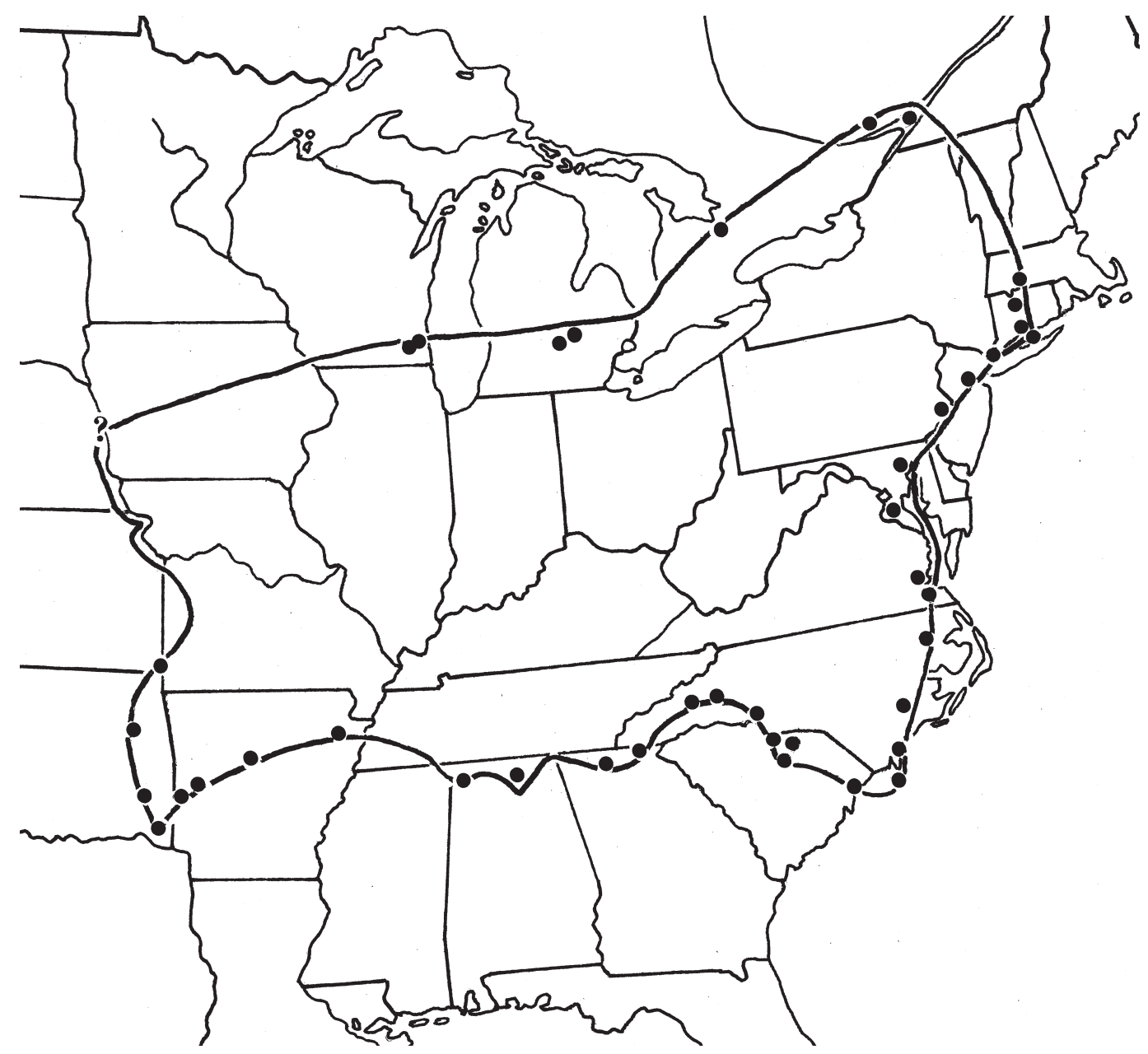

Fig. 1. Approximate projected distribution of Apheloria showing peripheral localities; a smooth curve is drawn through range extremities in all directions. The western border follows that of the Ozark Province north to the Missouri River floodplain, which it follows northward to Omaha. Some dots represent > 1 closely proximate locality; the question mark (?) denotes the record of Fontaria luminosa from Omaha, Nebraska (Kenyon 1893).

similar colors and patterns, Apheloria can be recognized by the diagnostic circular or "sickleshaped" gonopods (Attems 1938: fig. 186; Chamberlin 1939: figs. 29-31, 33-35; Chamberlin 1947: fig. 8; Hoffman 1949: figs. 1-2; Hoffman 1978: figs. 1, 3; Shelley 1978: figs. 65-66; Shelley 1988: fig. 34).

As with most Atlantic Coastal milliped taxa that traverse the Mississippi River, few published records of A. virginiensis exist from west of this watercourse. Hoffman (1999) recognized 2 "western" subspecies, both authored by Chamberlin (1939): A. v. iowa, which spans the river and occurs in eastern Iowa and western Illinois, and A. v. reducta, in the Ozark and Ouachita Plateaus of Arkansas and Missouri; the latter subspecies was also documented from the Ouachita Province in McCurtain Co., Oklahoma, by Causey (1954). Hoffman suggested that the taxa likely merge and that there may be only 1 "western" subspecies, but he did not synonymize the names and both presently stand; they occur on opposite sides of the Missouri River, which may divide their ranges.

The 1st published citations of Apheloria from west of the Mississippi River were by Chamberlin (1939) in the descriptions of A. iowa from Mt. Pleasant, Henry Co., Iowa (Fig 2, triangle), and A. reducta from Imboden, 


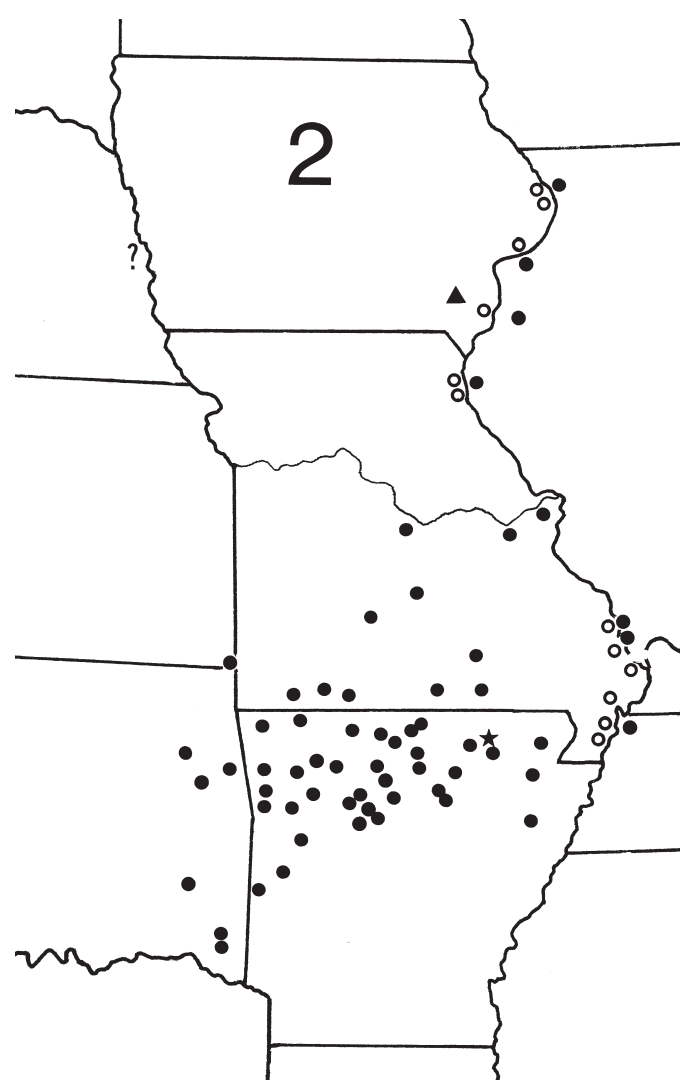

Fig. 2. Known and projected occurrences of A. virginiensis west of the Mississippi River, showing bordering sites to the east in Illinois and Tennessee and the course of the Missouri River through central Missouri. Dots = documented records; circles = projected localities directly opposite known sites east of the Mississippi River; triangle = type locality of $A$. iowa; star = type locality of $A$. reducta. The question mark (?) denotes the published record of Fontaria luminosa from Omaha; some dots in Arkansas represent $>1$ closely proximate localities.

Lawrence Co., Arkansas (Fig. 2, star). Causey (1952) reported A. reducta from Barry Co., Missouri, and 14 Arkansas counties that were subsequently referenced generally by Chamberlin and Hoffman (1958); 2 years later, she (Causey 1954) reported the milliped from an unspecified site in McCurtain Co., Oklahoma. After Chamberlin and Hoffman's summary, 28 years passed before more "western" localities were cited, of A. corrugata (Wood, 1864), from caves and a spring in 4 counties in Missouri (Gardner 1986). Hoffman (1999) reduced iowa and reducta to subspecific statuses under $A$. virginiensis and provided the aforementioned range summaries, though overlooking Causey's record (1954) from Oklahoma. McAllister et al. (2002) reported A. v. reducta from 2 localities in McCurtain Co., thereby confirming Causey's citation from the county in general. The same authors (McAllister et al. 2003) subsequently recorded the milliped from 23 ostensibly new Arkansas counties, 12 of which had been cited by Causey (1952) in a reference they missed.

In addition to these taxa, Fontaria luminosa Kenyon, 1893, potentially applies to 1 or both races, but its identity has never been unequivocally established. Kenyon (1893) proposed the binomial for a male and female from Omaha, Douglas Co., Nebraska, that purportedly had also been seen at Lincoln, Lancaster Co.; however, the latter city, located in the eastern Great Plains and removed from riparian habitats along the Missouri River at Omaha, seems implausible and is discounted herein. According to Kenyon, the gonopods consisted of a "long basal piece from which a small flattened process curves inward, forward, outward, and downward," a reasonable characterization of a circular structure by a nonspecialist in that era. Dorsally, the millipeds were "yellowish brown" with "a narrow yellow line" above the margins of each segment and "round yellow marks" near the lateral edges, which we interpret as a yellow transverse band along the caudal margin of each metatergite and yellow paranotal spots. The latter were purported to be the source of an uncorroborated "whitish phosphorescence," hence the specific name. Aside from the bioluminescent species of Motyxia in Tulare, Kern, and Los Angeles Cos., California (Shelley 1997), "phosphorescence" of any kind has not been reliably reported in a xystodesmid milliped. As noted by Shelley (1986), there is a xystodesmid sample from Omaha at the NMNH containing 1 male and 3 females with a label stating "Fontaria luminosa (Type?)," but the gonopods of the male are lost. Only 3 xystodesmids potentially occur at Omaha: P. flavipes, A. virginiensis, and Semionellus placidus (Wood, 1864); the millipeds in this sample are much too large and robust to be the last, and they lack the broad sternal lobes that diagnose P. flavipes (Shelley 1980, 1994). Apheloria virginiensis is thus the only possibility for these specimens if they are indeed from Omaha and are the types of $F$. luminosa. Topotypes are therefore necessary to resolve these questions, but RMS and our 
colleague R.L. Hoffman have searched for A. virginiensis in riparian forests along the Missouri River near Omaha without success; for the purposes of this contribution, we assume this occurrence. Hoffman (1999) therefore listed "Apheloria luminosa (Kenyon)" as a species of uncertain status until occurrence at or near Omaha is confirmed. He suggested that luminosa may be a senior name for A. iowa, whose type localities are at essentially the same latitude and considerably north of the northernmost records of $A$. v reducta, in Cole, Franklin, and St. Louis Cos., Missouri, south of the Missouri River (Fig. 2). However, we note that all records of both $A$. $v$. reducta and $F$. luminosa are on the same, western/southern, side of this watercourse, and the Nebraska records, if truly referring to Apheloria, could represent a northern population of $A$. $v$. reducta. Fontaria luminosa could therefore be a senior name for either reducta or iowa, so topotypical specimens are essential.

On 4 May 2005, CTM collected an adult male of A. v. reducta in the southeastern corner of Cherokee Co., Kansas, constituting the lst record of the genus, species, and subspecies from the state. The site is about $2 \mathrm{mi}$ $(3.2 \mathrm{~km})$ west of the Missouri state line and 5 mi $(8 \mathrm{~km})$ north of Oklahoma, and is in the Ozark Plateau Physiographic Province that extends only about $5 \mathrm{mi}(8 \mathrm{~km})$ into this corner of Kansas to the town of Baxter Springs. The milliped is black with yellow, triangular paranotal markings that continue slightly mediad along the caudal metatergal margins but do not extend into distinct transverse bands, although there are faint, narrow bands on segments 15-19. There is no band on the collum, and the epiproct is black basally and yellow apically. The specimen was encountered in typical upland Ozarkian habitat, beneath a partly buried oak log near a spring in the vicinity of Shoal Creek; the closest published record is that of Causey (1952) from an unspecified site in Barry Co., Missouri, which lies approximately $40 \mathrm{mi}(64 \mathrm{~km})$ to the southeast. We report here the Kansas locality along with unpublished localities from Missouri, Arkansas, and Oklahoma; we summarize the published records; and we map all the sites, thereby fully documenting the "western" occurrences of $A$. virginiensis (Fig. 2). As the generic range has never been documented, we also report new records from east of the Mis- sissippi, emphasize peripheral localities, project occurrences in all occupied US states and Canadian provinces, and map the projected distribution (Fig. 1). We provide complete citations for "eastern" states with 5 or fewer new counties and the states for counties with 6 or more; general citations are referenced when specific localities are not available. Missing data from the new records were not provided on the vial labels, and open symbols in fig. 2 represent projected occurrences in Iowa and Missouri that are directly opposite known sites east of the Mississippi River. Repository acronyms are as follows: AMNHAmerican Museum of Natural History, New York; BMNH-Natural History Museum, London; BYU-Monte L. Bean Life Science Museum, Brigham Young University, Provo, Utah; CMNH-Carnegie Museum of Natural History, Pittsburgh, Pennsylvania; CLMNH-Cleveland Museum of Natural History, Cleveland, Ohio; CTM-private collection of C.T. McAllister; DMNH-Dayton Museum of Natural History, Dayton, Ohio; EIL-Biology Department, Eastern Illinois University, Charleston; FMNH- Field Museum of Natural History, Chicago, Illinois; FSCA-Florida State Collection of Arthropods, Gainesville; HUD-Hudsonia Environmental Research Institute, Bard College, Annandale, New York; INHS-Illinois Natural History Survey, Champaign; JAB-private collection of J.A. Beatty, Carbondale, Illinois; LSU-Museum of Zoology, Louisiana State University, Baton Rouge; MCZ-Museum of Comparative Zoology, Harvard University, Cambridge, Massachusetts; MEM-Mississippi Entomological Museum, Mississippi State University, Starkville; MHNG-Muséum d'Histoire Naturelle, Geneva, Switzerland; MPM-Milwaukee Public Museum, Milwaukee, Wisconsin; NCSM-North Carolina State Museum of Natural Sciences, Raleigh; NMNHNational Museum of Natural History, Smithsonian Institution, Washington, DC; OKSUEntomology Department, Oklahoma State University, Stillwater; OMNH-Sam Noble Oklahoma Museum of Natural History, Norman; PMNH-Peabody Museum of Natural History, Yale University, New Haven, Connecticut; PSU-Entomology Department, Pennsylvania State University, State College; SIU-Biology Department, Southern Illinois University, Carbondale; TMM-Texas Memorial Museum, University of Texas, Austin; UAAM-University of 
Arkansas Arthropod Museum, Fayetteville; UCO-University of Colorado Museum, Boulder; UMMZ-University of Michigan Museum of Zoology, Ann Arbor; VMNH-Virginia Museum of Natural History, Martinsville. WVDAWest Virginia Department of Agriculture, Charleston.

\section{Published Range Statements AND RECORDS}

Eastern North America from Vermont and southern Ontario south to North Carolina, Tennessee, and Arkansas, northwest to eastern Iowa (Chamberlin and Hoffman 1958). New England to Georgia in the mountains, and westward as far as Oklahoma and Iowa, represented in the Central Lowlands and Atlantic Coastal Plain as well as in the Appalachian region (Hoffman 1978). The northern twothirds of eastern North America from a line extending from central New York through southern Ontario, southern Wisconsin, and northern Iowa south to central Arkansas, northern Alabama, and northern South Carolina; longitudinally from along the Atlantic Ocean from southeastern North Carolina to central Connecticut west to eastern Oklahoma and southeastern Nebraska (Shelley 1986). Northeastern and central United States (Hoffman 1999).

\section{Canada}

QuéBEC: Argenteuil and Vaudreuil Census Divisions (CD), Île de Montréal (Shelley 1988). Montreal (Hoffman 1999).

Ontario: Southern Ontario (Kevan 1983, Shelley 1986), eastern Ontario (Kevan 1983). Haldimand-Norfolk, Hamilton-Wentworth, Kent, Lanark, Niagara, Prince Edward, and York Cos. (Shelley 1988).

\section{United States of America}

New Hampshire: New Hampshire in general (Kevan 1983).

VERMONT: Vermont in general (Kevan 1983).

Massachusetts: Massachusetts in general (Chamberlin and Hoffman 1958, Kevan 1983).

Connecticut: Central Connecticut (Shelley 1986).

NEw YorK: Finger Lakes region (Chamberlin and Hoffman 1958). Central New York (Shelley 1986). Oneida and Tompkins Cos.
(Wood 1864, Attems 1938, Chamberlin 1939, 1951, Causey 1955, Chamberlin and Hoffman 1958).

Pennsylvania: Potter and Washington Cos. (Chamberlin 1947).

MaRYLAND: Garrett Co. (Chamberlin 1947).

West Virginia: Pendleton Co. (Causey 1955).

VIRGINIA: South central Virginia (Chamberlin and Hoffman 1958). Southwestern Virginia, Piedmont and inner Coastal Plain (Hoffman 1999). Dinwiddie, Floyd, Franklin, Pittsylvania, Scott, Surry, and Washington Cos. (Chamberlin 1939, Chamberlin and Hoffman 1958, Hoffman 1978, 1999, Shelley 1980).

North Carolina: Region adjacent to south central Virginia (Chamberlin and Hoffman 1958). Fall Zone region (Shelley 1977). Coastal southeastern North Carolina (Shelley 1986, Hoffman 1999). Alamance, Alexander, Alleghany, Ashe, Avery, Bladen, Brunswick (including Bald Head Island), Buncombe, Caldwell, Caswell, Chatham, Chowan, Columbus, Craven, Cumberland, Davidson, Durham, Edgecombe, Forsyth, Franklin, Granville, Guilford, Halifax, Harnett, Jackson, Johnston, Lee, Madison, McDowell, Mitchell, Moore, New Hanover, Orange, Person, Richmond, Robeson, Rockinghan, Sampson, Stanly, Stokes, Surry, Wake, Warren, Watauga, Wayne, Wilkes, Union, Yadkin, and Yancey Cos. (Brimley 1938, Chamberlin 1939, 1940, Loomis 1944, Chamberlin and Hoffman 1958, Wray 1967, Shelley 1978, 2000, Hoffman 1999).

South Carolina: Northern South Carolina (Shelley 1986).

GEORGIA: Northern Georgia (Hoffman 1999).

Alabama: Northern Alabama (Shelley 1986, Hoffman 1999).

Tennessee: Central and eastern Tennessee (Hoffman 1999). Cocke, Davidson, Knox, Rhea, Roane, and Unicoi Cos. (Bollman 1887, Chamberlin 1921, 1939, 1947, 1949, Attems 1899, 1938, Chamberlin and Hoffman 1958, Hoffman 1978, 1999).

KenTUCKY: Eastern Kentucky (Chamberlin and Hoffman 1958). Southeastern Kentucky (Hoffman 1999). Bell, Edmonson, and Harlan Cos. (Chamberlin 1947, Causey 1950, 1955, Chamberlin and Hoffman 1958, Hoffman 1999).

Oнiо: Abundant in southeast, rare in north (Williams and Hefner 1928). Gallia Co. (Morse 1902).

INDIANA: Southern Indiana (Chamberlin and Hoffman 1958). Benton, Crawford, Franklin, 
Howard, Monroe, Tippecanoe, and Wayne Cos. (Bollman 1888, McNeill 1888, Chamberlin and Hoffman 1958, Hoffman 1999).

Michigan: Eastern Michigan (Kevan 1983). Branch, Hillsdale, Ingham, Jackson, Lenawee, Livingston, Monroe, Washtenaw, and Wayne Cos. (Snider 1991).

Wisconsin: Southern Wisconsin (Shelley 1986).

IowA: Northern Iowa (Shelley 1986). Eastern Iowa (Hoffman 1999). Henry Co., Mt. Pleasant (Chamberlin 1939, Chamberlin and Hoffman 1958, Hoffman 1999).

Missouri: Southwestern Missouri (Chamberlin and Hoffman 1958). Barry Co. (Causey 1952). Howell, Oregon, Pulaski, and Shannon Cos. (Gardner 1986).

ARKANSAS: "About 14 counties in northwestern Arkansas" (Chamberlin and Hoffman 1958). Lawrence Co., Imboden (Chamberlin 1939, Causey 1954, Chamberlin and Hoffman 1958, Hoffman 1999). Benton, Carroll, Cleburne, Greene, Independence, Johnson, Logan, Newton, Polk, Scott, Searcy, Sharp, Stone, and Washington Cos. in general (Causey 1952). Sites in Baxter, Benton, Boone, Carroll, Cleburne, Conway, Craighead, Crawford, Cross, Franklin, Independence, Johnson, Logan, Madison, Marion, Newton, Polk, Pope, Scott, Searcy, Stone, Van Buren, and Washington Cos. (McAllister et al. 2003).

OKLAHомa: Eastern Oklahoma (Shelley 1986). McCurtain Co. (Causey 1954), Beavers Bend St. Pk. and Broken Bow (McAllister et al. 2002).

Nebraska: Southeastern Nebraska (Shelley 1986). Douglas and Lancaster Cos. (Kenyon 1893 [questionable records based on "Fontaria luminosa"], Shelley 1986).

South Dакота: Southeastern South Dakota along the Missouri River (Shelley 1986, predicted occurrence yet to be verified).

\section{Deletions}

New Hampshire; Lincoln, Lancaster Co., Nebraska. While the xystodesmid Sigmoria (Rudiloria) trimaculata trimaculata (Wood, 1864) occurs in New Hampshire (Shelley 1996), Apheloria has never been collected there, nor is any part of the state encompassed by the projected range (Fig. 1). Kenyon's (1893) record of F. luminosa from Lincoln, which is on the Central Plains and removed from riparian, riverine habitats with deciduous leaf litter, is implausible for Apheloria.

\section{Projected Occurrences AND NEW RECORDS \\ Canada}

QuÉBEC: Southern Québec around Montreal and neighboring census divisions bordering Ontario and New York. Vaudreuil CD, Rigaud, ㅊ, 2 ㅇ, 18 May 1981, L. LeSage (NCSM). Deux-Montagnes CD, Oka, Calvaire d'Oka (road to the Cross within Oka), \&, 19 September 2001, R. Vignault (VMNH). Northernmost locality and generic record: Montreal (Hoffman 1999).

Ontario: Southern Ontario east of a line extending from southern Lake Huron and Georgian Bay to the vicinity of Ottawa. Lanark Co., Murphys Point Prov. Pk.,,+ 17 June 1982, L. LeSage (NCSM). Westernmost locality: Simcoe Co., Craighurst, 2 \%, Fall 1969, J. Burke (FSCA).

\section{United States of America}

VERMONT: No definite records but anticipated in the western/southwestern one-third of the state.

Massachusetts: Expected west of the Connecticut River. Hampden Co., Springfield, q (MCZ). First state locality.

Connecticut: Expected west of the Connecticut River. Fairfield Co., Wilton, Wier Pres. nr. Ridgefield, ô, 12 July 1981, M.W. Klemens (AMNH). Hartford Co., Canton, Onion Mtn., ô, 31 May 1981, J. Pratt (NCSM). Litchfield Co., Salisbury, o, 19 June 1936, C.H. Blake (MCZ); and Pine Grove, New Caanan, ô, 29 June 1932 (PMNH). New Haven Co., New Haven, ô, + , ca. 1871, O. Harger (PMNH); and Thimble Islands, Outer Island, 1890, A.E. Verrill (PMNH), easternmost locality. First state localities.

New York: Statewide except Long Island. Dutchess, Essex, Fulton, Greene, Onondaga, Orange, Schuyler, Steuben, Ulster, Warren, Washington, and Yates Cos. (AMNH, HUD, MCZ, NCSM, NMNH). Southernmost locality: New York Co., New York City, Manhattan, Columbia Univ. campus, o (NMNH).

New Jersey: Northern half of the state north of the "neck" extending from Trenton to Raritan Bay. Bergen Co., Englewood, ô, 22 
June 1907, G. von Krokow (UMMZ); Palisades, §, 7 September 1908, W.J. Gertsch (AMNH); Mahwah, o, 2 \%, 11 May 1941, W.J. Gertsch (AMNH); and Ramsey, ô, 10 June 1944, W.J. Gertsch (AMNH). Essex Co., Short Hills, 3 \% 13 June 1908 (AMNH); and East Orange, ô, ㅇ, 10 July 1910, R.V. Chamberlin (NMNH). Morris Co., Newfoundland, ô, 28 May 1910, H.J. Lutz (AMNH). Southernmost locality: Union Co., Somerset, nr. Plainfield, ô, 23 May 1909, A.W. Millar (AMNH). New state record.

Pennsylvania: Statewide. Allegheny, Armstrong, Berks, Blair, Bucks, Cambria, Fayette, Huntington, Northampton, and Warren Cos. (AMNH, BYU, CMNH, PSU, VMNH).

DELAWARE: Unknown from the state but expected in the northern extremity west of Wilmington and north of Highway I-95.

MARYLAND: Expected in the northeastern corner and west of Chesapeake Bay; probably absent from the "eastern shore." Frederick Co., Catoctin Mtn. Park, ㅇ, 25 May 1970, T.J. Spilman (NMNH). Montgomery Co., Plummers I. in Potomac R., ô $\hat{\delta}$, $q$ ㅇ, 1 and 20 May and 20 July 1902, H.S. Barber, H.A. Baum, and R.F. Griggs (NMNH); Bell Sta. on Western Branch R.R., + , 22 February 1916, H.F. Loomis (VMNH); and Little Bennett Regional Park, ô, 2 June 1989, W.E. Steiner (NMNH). Easternmost records: Baltimore Co., Baltimore, ô, 25 July 1913 (BMNH). Charles Co., ô, 우, O. Bryant (MCZ).

District of Columbia: Districtwide. Rock Creek Park, ô, 6 April 1905, O.F. Cook (VMNH); and near Potomac R. just above Washington, ô, 8 April 1910, O.F. Cook (NMNH). New record.

West Virginia: Statewide. Barber, Berkeley, Boone, Braxton, Calhoun, Clay, Greenbrier, Hampshire, Kanawha, McDowell, Mercer, Nicholas, Pendleton, Raleigh, Randolph, Roane, Ritchie, Summers, Upshur, Wayne, Webster, and Wyoming Cos. (BYU, MCZ, NCSM, NMNH, VMNH, WVDA).

VIRGINIA: Expected throughout Virginia west of Chesapeake Bay; apparently absent from the "eastern shore" and the southeastern corner east of the western border of the Great Dismal Swamp, including metropolitan Norfolk, Portsmouth, and Virginia Beach. Alleghany, Amherst, Appomattox, Augusta, Bedford, Botetort, Buchanan, Buckingham, Caroline, Carroll,
Chesterfield, Cumberland, Dickinson, Fairfax, Fauquier, Fluvanna, Frederick, Giles, Grayson, Greensville, Halifax, Hanover, Henrico, Henry, James City, Jefferson, Lee, Loudoun, Louisa, Lunenberg, Madison, Mecklenburg, Montgomery, Page, Patrick, Prince Edward, Pulaski, Roanoke, Rockbridge, Russell, Shenandoah, Smyth, Southampton, Stafford, Sussex, Tazewell, Warren, Wise, and Wythe Cos. (BYU, FMNH, MCZ, NCSM, NMNH, VMNH). Easternmost localities: York Co., ca. $8 \mathrm{mi}(12.8 \mathrm{~km}) \mathrm{NW}$ Yorktown $(4.8 \mathrm{mi}[7.7 \mathrm{~km}] \mathrm{NE}$ Williamsburg, James City Co.), 5-6 sites on Cheatham Annex Naval Supply Center, $15 \hat{0}, 9+$, juv., 19 June 1989-30 May 1990, K.A. Buhlman (VMNH). City of Suffolk, Magnolia, Jct. U.S. Hwys. 58 and 460, W side of Great Dismal Swamp, o, 4 May 1956, R.H. Pageot (VMNH).

North Carolina: Occurring throughout most of the state west of the inner extremities of Albemarle, Pamlico, and Bogue Sounds; absent from the southwestern Piedmont and the southeastern Blue Ridge Mountains. All peripheral localities were referenced generally by county by Shelley (2000). Easternmost localities: Brunswick Co., Brunswick Town State Hist. Site, 2ô, 2 q , 3 November 1986, R.M. Shelley (NCSM). Chowan Co., $8.6 \mathrm{mi}$ (13.8 km) E Edenton, along SR 1100, ㅇ, 27 April 1984, J.C. Beane, M.K. Clark, P. Trail (NCSM); and $4.5 \mathrm{mi}(7.2 \mathrm{~km}) \mathrm{SE}$ Edenton, along NC Hwy. 32, ô, 27 May 1990, J.C. Beane (NCSM). Craven Co., $8 \mathrm{mi}(12.8 \mathrm{~km})$ NW New Bern, along U.S. Hwy. 70, $1 \mathrm{mi}(1.6 \mathrm{~km}) \mathrm{E}$ Batchelor Cr., ô, 14 October 1977, R.M. Shelley, J.C. Clamp (NCSM). New Hanover Co., Carolina Beach St. Pk., +, 19 September 1981, A.L. Braswell (NCSM). Southeasternmost locality: Brunswick Co., Bald Head Island, 26 July 1984, C. Meekins (NCSM). Southwesternmost localities: Buncombe Co., $8.8 \mathrm{mi}$ (14.1 km) SSW Asheville, Bent Creek Forest Exp. Sta., Pisgah Nat. For., ô, 14 July 1958, R.L. Hoffman (VMNH) and Lake Powhatan Rec. Area, ô, 2 ㅇ, 5 September 1977, R.M. Shelley (NCSM). McDowell Co., $9.6 \mathrm{mi}(15.1 \mathrm{~km}) \mathrm{NW}$ Marion, ô, 25 July 1975, R.M. Shelley, J.C. Clamp (NCSM). Union Co., 4-7 mi (6.4-11.2 km) NE Monroe, jct. St. Rts. 1764 and 1631, o, 15 July 1978, D.L. Stephan, J. Perry (NCSM); and $1.5 \mathrm{mi}(2.4 \mathrm{~km}) \mathrm{NE}$ Monroe, along NC Hwy. 200 at Bearskin Cr., ô, 9 July 1980, A.L. Braswell (NCSM). 
South Carolina: The northeastern and north central border region, represented by 3 records in the northeastern Piedmont and a Coastal Plain site approximately $100 \mathrm{mi}$ (160 $\mathrm{km}$ ) eastward on the "Grand Strand." Chesterfield Co., Cheraw, + , 3 July 1958, K. Dawson (FSCA); $4 \mathrm{mi}(6.4 \mathrm{~km}) \mathrm{N}$ Chesterfield, along SC Hwy. 145, 3 ô, 우, 12 July 1979, R.M. Shelley, R.K. Tardell (NCSM); and along SC Hwy. 9, $0.4 \mathrm{mi}(0.6 \mathrm{~km}) \mathrm{E}$ Lynches Rd., 30े, ㅇ, 12 July 1979, R.M. Shelley, R.K. Tardell (NCSM). Southernmost Piedmont locality: Kershaw Co., $11 \mathrm{mi}(17.6 \mathrm{~km})$ NNE Camden, along SC Hwy. 40 at Flat Rock Cr., 40ิ, 3ㅇ, 12 July 1979, R.M. Shelley, R.K. Tardell (NCSM). Atlantic Coastal locality and southeasternmost generic record: Georgetown Co., Brookgreen Gardens, along U.S. Hwy. 17 ca. 2 mi $(3.2 \mathrm{~km}) \mathrm{N}$ Litchfield Beach, ô, 14 June 1971, M. Kosztarab (VMNH). First state localities.

GEORGIA: Mountains and the northernmost tier of counties; apparently absent from Rabun, the northeasternmost county. Fannin, Murray, Towns, Union, and Walker Cos. (MHNG, VMNH). Southernmost locality: Gilmer Co., $4 \mathrm{mi}(6.4 \mathrm{~km})$ NE Elijay, ô, 3 July 1963, R.L. Hoffman (MHNG). First state localities.

Alabama: Northern tier of counties north of the Tennessee River. Lauderdale Co., W of Florence, slope of Tennessee R., $\hat{0}, 2$ ㅇ, 16 April 1966, J.E. and M.R. Cooper (FSCA); and $5 \mathrm{mi}(8 \mathrm{~km}) \mathrm{SW}$ Florence, $2 \hat{\jmath}$, 8 April 1969, M.R. Cooper (NCSM). Southernmost locality: Madison Co., Huntsville, Monte Santo St. Pk., §ิ, 23 May 1980, R.M. Shelley, M.S. Morgan (NCSM). First state localities.

Tennessee: Expected statewide except the southwestern corner and the counties bordering Mississippi. Anderson, Bledsoe, Blount, Campbell, Claiborne, DeKalb, Dickson, Greene, Grundy, Johnson, Hancock, Loudon, Macon, Maury, McMinn, Monroe, Morgan, Obion, Overton, Polk, Putnam, Robertson, Scott, Sevier, Smith, Sullivan, Van Buren, Washington, Wayne, and Wilson Cos. (FSCA, INHS, LSU, MCZ, NCSM, TMM, UMMZ, VMNH).

Kentucky: Statewide. Barren, Carter, Cumberland, Jackson, Laurel, Lawrence, Lee, Lyon, Madison, McCreary, Meade, Menifee, Metcalf, Monroe, Morgan, Pike, Pulaski, Warren, and Wayne Cos. (DMNH, FMNH, FSCA, JAB, MHNG, NCSM, NMNH, UCO, UMMZ, $\mathrm{VMNH}$.
OHı: Statewide. Adams, Ashland, Athens, Butler, Crawford, Fairfield, Greene, Hocking, Lawrence, Licking, Montgomery, Morgan, Muskingum, Pike, Scioto, Vincent, Vinton, Washington, and Wayne Cos. (FSCA, MCZ, CLMNH, DMNH, NCSM, NMNH, PMNH, VMNH).

Indiana: Statewide. Dearborn, Jefferson, Lawrence, Morgan, Owen, Parke, and Porter Cos. (FMNH, FSCA, INHS, VMNH).

Illinois: Statewide. Adams, Alexander, Carroll, Champaign, Clark, Coles, Cook, Edgar, Effingham, Franklin, Jackson, Jersey, Johnson, Macoupin, McLean, Morgan, Piatt, Pope, Rock Island, Union, Wabash, Warren, and Washington Cos. (EIL, FMNH, FSCA, INHS, JAB, MCZ, SIU, VMNH). New state record.

Michigan: Southern one-third of the Lower Peninsula; no new county records. Northernmost locality: Livingston Co., East of South George Reservoir, o, 17 July 1947, K. Bohnsack (UMMZ).

Wisconsin: Southern periphery and the southeastern corner. Milwaukee Co., o, ㅇ, 4 May 1905 (AMNH), and $\widehat{o}$, F. Rauterberg (MPM). Waukesha Co., Big Bend, ô, 20 May 1933, W.E. Dickinson (MPM). First state localities.

Iowa: Distribution unknown with only 1 record; projected as the southeastern third of the state, extending northward in the east along the Mississippi River.

Missouri: Expected in all but the western Great Plains south of Kansas City; presently known only from south of the Missouri River. Cole Co., ô, 2 ㅇ, 20 September 1965, 3 ㅇ, 16 July 1968, and $\delta$,,+ 5 August 1965, W.W. Dowdy (FSCA). Franklin Co., Grayson, ㅇ, 7 August 1955, L. Hubricht (MHNG). Oregon

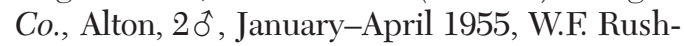
ton (FSCA). Stone Co., ô, April 1962, H.H. Leake (FSCA). Taney Co., ô, April 1962, H.H. Leake (FSCA). Northernmost locality: St. Louis Co., Babler Park, along U.S. Hwy. 40 ca. 25 mi (40 km) W St. Louis, ô, 14 August 1956, R.E. Crabill, Jr. (MHNG).

ARKANSAS: Northeastern periphery and the northwestern half of the state from south of the "heel" of Missouri southwestward to the southern border of the Ouachita Physiographic Province in Polk Co. Baxter Co., $5 \mathrm{mi}(8$ km) E Big Flat, ô, 30 July 1955, L. Hubricht (MHNG). Conway Co., Petit Jean St. Pk., ô, 6 August 1955, L. Hubricht (MHNG); and southern edge Petit Jean St. Pk. along AR Hwy. 155, 
§ิ, 16 April 2005, S.E. Trauth, B. Wheeler (CTM). Craighead Co., Jonesboro, ôे ô, 우 November 1956 (FSCA). Fulton Co., 1 mi (1.6 km) W Salem, + , 15 April 2005, S.E. Trauth, B. Wheeler (CTM). Marion Co., along Co. Rd. 144, $1.5 \mathrm{mi}(2.4 \mathrm{~km}) \mathrm{SW}$ jct. Co. Rd. 143, §, 15 April 2005, S.E. Trauth, B. Wheeler (CTM). Newton Co., $1 \mathrm{mi}$ (1.6 km) N Pelsor, Boston Mts., ․ 28 August 1955, L. Hubricht (MHNG). Polk Co., Mena, +16 March 1956, A. McWilliams (FSCA), southernmost locality; and $12 \mathrm{mi}$ (19.2 km) NW Mena, Black Fork Mtn., 20, 4 May 1993, H.W. Robison (VMNH). Pope Co., $5 \mathrm{mi}$ (8 km) N Scottsville, 6 February 1955 (FSCA); $9 \mathrm{mi}(14.4 \mathrm{~km}) \mathrm{N}$ Dover, Boston Mts., 2 ㅇ, 28 August 1955, L. Hubricht (MHNG); and Illinois Bayou, along AR Hwy. 27, $3 \mathrm{mi}(4.8 \mathrm{~km})$ N Hector, +, 16 April 2005, S.E. Trauth, B. Wheeler (CTM). Randolph Co., Hansell Cave, ․, 22 April 1969, D. Barnett (FSCA). Searcy Co., $2.5 \mathrm{mi}$ (4 km) SE Leslie, ô, 31 July 1955, L. Hubricht (MHNG). Stone Co., Blanchard Springs, 2 ô, 18 May 1973, D.H. Kavanaugh, H. Goulet (NMNH); and Gustafson Cave, + , 6 October 2002, G. Graening, S. McGinnis, C. Brickey (UAAM). Washington Co., Winslow, ๙, 27 October 1957, M. Hite (FSCA). Easternmost locality in Ouachita Physiographic Province: Conway Co., $5 \mathrm{mi}(8 \mathrm{~km})$ N St. Vincent (McAllister et al. 2003).

OKLahoma: Eastern periphery. Adair Co., Three Forks Cave, $9 \mathrm{mi}(14.4 \mathrm{~km}) \mathrm{N}$ Bunch, 우, 1971, J.H. Black (FSCA). Cherokee Co., along stream, ㅇ, 28 May 1954, A. Bragg (OMNH). Latimer Co., juv., 16 June 1951, Wisher $(\mathrm{OMNH})$. Westernmost locality and generic record: Mayes Co., Locust Grove, ô, 2 \%, 20 May 1972, D.C. Arnold (OKSU). Southernmost locality and generic record: McCurtain Co., Broken Bow (McAllister et al. 2002).

KANSAS: Projected for the Missouri River floodplain north of Kansas City and the extreme southeastern corner, but only 1 record. Cherokee Co., $1 \mathrm{mi}(1.6 \mathrm{~km}) \mathrm{S}$ Galena, Schermerhorn Park on KS Hwy. 26, ô, 4 May 2005, C.T. McAllister (NCSM). New state record.

NEBRASKa: Riparian eastern fringe along the Missouri River; no new or definite records.

\section{Discussion}

These constitute a limited number of "western" records except for the Ozark and Oua- chita regions of Arkansas, and substantial field collecting is needed to fully document the distribution in this part of the generic range. The type locality of A. iowa (Fig. 2, triangle) is the only record from Iowa, so the actual distribution here and whether A. v. iowa links with " $F$. luminosa" in Nebraska are unknown. However, the milliped can be reasonably expected in Jackson, Clinton, Scott, and Des Moines Cos., on the Mississippi River directly opposite Carroll, Rock Island, and Warren Cos., Illinois, where it does occur (samples in the INHS and $\mathrm{VMNH}) ; A$. $v$. reducta can also be anticipated in Scott Co. and the "heel" (New Madrid and Peniscott Cos.) of Missouri, which are across the Mississippi from the Reelfoot Lake, Obion Co., Tennessee, locality (VMNH). The known distribution of A. v. reducta in Arkansas corresponds closely with highland areas in the Ozark and Ouachita Physiographic Provinces, which have been heavily sampled in contrast to lowland areas to the east; consequently, this correlation may be an artifact of sampling practices. The presence of $A$. $v$. reducta in southeastern Oklahoma suggests occurrence in neighboring northeastern Texas (Bowie Co. and adjacent counties), but the McCurtain Co. sites are on the border of the Ouachita Province and have substantial hardwood forests; south of Broken Bow, the habitat changes to essentially pure pine, which lacks the deciduous leaf litter that xystodesmids prefer. We therefore suspect that $A$. $v$. reducta is absent from the southeasternmost corner of McCurtain Co.; CTM and students have sampled in Bowie Co. and in northeastern Texas for 5 years without finding it. We have also worked substantially in the Coastal Plain Physiographic Province of southwestern Arkansas (Little River, Hempstead, Miller, Lafayette, and Columbia Cos.) and northwestern Louisiana (Caddo Parish) without encountering it, so we think the xystodesmid does not inhabit these areas. Thus, though Arkansas east of the Ouachitas has been poorly investigated, the milliped's absence from the heavily sampled adjoining corners of Texas, Arkansas, and Louisiana suggests that its absence from Coastal Plain areas to the north may be real.

Overall, the projected distribution of Apheloria covers around 530-950 miles (848-1520 $\mathrm{km})$ north-south, and 970-1190 miles (1552$1904 \mathrm{~km}$ ) east-west (Fig. 1). The range spreads 
farther north in the east and extends from southern Québec, Michigan, and Wisconsin to northeastern-north central South Carolina, northern Georgia and Alabama, and southeastern Oklahoma; east-west, it extends from the Connecticut River, metropolitan New York City, the western shore of Chesapeake Bay, Bald Head Island, North Carolina, and the "Grand Strand" of South Carolina to Mayes Co., Oklahoma, and, presumably, the western floodplain of the Missouri River in eastern Nebraska. It encompasses parts of 2 Canadian provinces and 27 U.S. states plus the District of Columbia, including all of Pennsylvania, West Virginia, Kentucky, Ohio, Indiana, and Illinois, all of New York except Long Island, all of Tennessee except the southwest, and all of Missouri except the Great Plains south of the Missouri River. Apheloria spans southern Lake Michigan, all of Lakes Erie and Ontario, and all or parts of such major rivers as the St. Lawrence, Hudson, Delaware, Potomac, York, James, Roanoke, Neuse, Cape Fear, Tennessee, Cumberland, New/Kanawha, Ohio, Wabash, Illinois, Mississippi, Missouri, Arkansas, and Canadian. The Connecticut and Tennessee rivers form apparent boundaries in the northeast / New England and Alabama, respectively, as does Chesapeake Bay in Maryland and Virginia. Apheloria occurs on 2 offshore islands / island groups-Bald Head, in the Atlantic Ocean off the southeastern corner of North Carolina, and the Thimbles, in Long Island Sound south of Stony Creek, Connecticut. Occurrence is projected for parts of Vermont and Delaware, but the genus is deleted from New Hampshire and the vicinity of Lincoln, Nebraska, which are areas incompatible with present knowledge. Mississippi lies wholly outside the distribution, as only the extreme northeastern corner (of Tishomingo Co.) bordering the Tennessee River is even plausible. The predicted occurrence of Apheloria along the Missouri River in southeastern South Dakota (Shelley 1986) was speculative but not unreasonable if it does inhabit riverine forests at Omaha, only around $90 \mathrm{mi}(144 \mathrm{~km})$ to the south. Below Vermillion, the southeastern corner of South Dakota extends southward between Iowa and Nebraska and the Big Sioux and Missouri rivers; this area has never been sampled for millipeds and warrants investigation for potential taxa like Pleuroloma, Narceus, and Auturus Chamber- lin, 1942 (Polydesmida: Euryuridae), as well as Apheloria. Sampling is also needed in the projected range in Kansas, particularly along the Missouri River above Kansas City, and Iowa, to obtain more state records. The most urgent need, however, is an adult male from eastern Nebraska to confirm the assignment of F. luminosa to Apheloria (Shelley 1986, Hoffman 1999).

\section{ACKNOWLEDGMENTS}

We thank the following curators, collection managers, faculty, and students for loaning or providing records and access to samples in their institutional holdings: L. Prendini (AMNH), J. Beccaloni (BMNH), R.W. Baumann (BYU), J. Rawlins (CMNH), J. Hannibal (CLMNH), G. Coovert (DMNH), R. Funk (EIL), P. Sierwald (FMNH), G.B. Edwards (FSCA), E. Kiviat (HUD), V. Moseley (LSU), L. Leibensperger (MCZ), T.L. Schiefer (MEM), P. Schwendinger (MHNG), J.P. Jass (MPM), J. Coddington (NMNH), D.C. Arnold (OKSU), J.K. Braun (OMNH), R.S. Pupedis (PMNH), K.C. Kim (PSU), J.A. Beatty (SIU), J.R. Reddell (TMM), J.K. Barnes (UAAM), S.-K. Wu (UCO), M.J. O’Brien (UMMZ), R.L. Hoffman (VMNH), and M.C. Thomas (WVDA). We particularly thank S.E. Trauth, B. Wheeler, H.W. Robison, and J.T. McAllister, III, for collecting specimens in Arkansas; L. LeSage for placing localities in Québec; J.A. Beatty for providing access to his private collection; and R.L. Hoffman for advising about Apheloria based on his 60 years of experience with the genus.

\section{Literature Cited}

Attems, C. 1899. System der Polydesmiden II Theil. Denkschriften der Mathematisch-naturwissenschaftlichen Classe der Kaiserlichen Akademie der Wissenschaften 68:241-435.

1938. Myriapoda 3. Polydesmoidea II, fam. Leptodesmidae, Platyrhacidae, Oxydesmidae, Gomphodesmidae. Das Tierreich Lief. 69:1-487.

Bollman, C.H. 1887. Descriptions of fourteen new species of North American myriapods. Proceedings of the United States National Museum 10:617-627.

1888. Catalogue of the myriapods of Indiana. Proceedings of the United States National Museum 11: 403-410.

BRImLEy, C.S. 1938. The insects of North Carolina. North Carolina Department of Agriculture, Division of Entomology. 560 pp.

Causey, N.B. 1950. A collection of xystodesmid millipeds from Kentucky and Tennessee. Entomological News 61:5-8. 
1952. Some records and descriptions of polydesmoid millipeds from the United States. Chicago Academy of Sciences Natural History Miscellanea No. 106:1-11.

1954. Three new species and new records of southern millipeds. Tulane Studies in Zoology 2(4): $63-68$.

1955. New records and descriptions of polydesmoid millipeds (order Polydesmida) from the eastern United States. Proceedings of the Biological Society of Washington 68:21-30.

Chamberlin, R.V. 1921. On some chilopods and diplopods from Knox Co., Tennessee. Canadian Entomologist 53:230-233.

1939. On some diplopods of the family Fontariidae. Bulletin of the University of Utah 30(2) [Biological Series 5(3)]:1-19.

1940. Four new polydesmoid millipeds from North Carolina (Myriapoda). Entomological News 51:282284.

1947. Some records and descriptions of diplopods chiefly in the collection of the Academy. Proceedings of the Academy of Natural Sciences of Philadelphia 99:21-58.

1949. Some millipeds of the families Polydesmidae and Xystodesmidae. Journal of the Washington Academy of Sciences 39(3):94-102.

1951. Records of American millipeds and centipeds collected by Dr. D. Elden Beck in 1950. Great Basin Naturalist 11(1-2):27-35.

Chamberlin, R.V., and R.L. Hoffman. 1958. Checklist of the millipeds of North America. United States National Museum Bulletin 212:1-236.

GARDNER, J.E. 1986. Invertebrate fauna from Missouri caves and springs. Missouri Department of Conservation Natural History Series No. 3:1-72.

Hoffman, R.L. 1949. The identity of Apheloria coriacea (Diplopoda, Xystodesmidae). American Museum Novitates Number 1405:1-6.

1978. Revalidation of the generic name Rudiloria Causey, 1955 (Polydesmida: Xystodesmidae). Myriapodologica No. 1:1-7.

1999. Checklist of the millipeds of North and Middle America. Virginia Museum of Natural History Special Publication No. 8:1-584.

KeEton, W.T. 1960. A taxonomic study of the milliped family Spirobolidae (Diplopoda: Spirobolidae). Memoirs of the American Entomological Society No. 17: 1-146.

Kenyon, F.C. 1893. A preliminary list of the Myriapoda of Nebraska, with descriptions of new species. Publications of the Nebraska Academy of Sciences 3:14-18.

Kevan, D.K. McE. 1983. A preliminary survey of known and potentially Canadian millipedes (Diplopoda). Canadian Journal of Zoology 61:2956-2975.

Loomis, H.F. 1944. Millipeds principally collected by Professor V.E. Shelford in the eastern and southeastern states. Psyche 51(3-4):166-177.

McAllister, C.T., R.M. Shelley, and J.T. McAllister, III. 2002. Millipeds (Arthropoda: Diplopoda) of ArkLa-Tex. II. Distributional records for some species of western and central Arkansas and eastern and southeastern Oklahoma. Journal of the Arkansas Academy of Science 56:95-98.

. 2003. Millipeds (Arthropoda: Diplopoda) of ArkLa-Tex. III. Additional records from Arkansas. Journal of the Arkansas Academy of Science 57:115-121.
MCNeill, J. 1888. A list, with brief descriptions of all the species, including one new to science, of Myriapoda of Franklin Co., IND. Bulletin of the Brookville Society of Natural History No. 3:1-20.

Monse, M. 1902. Myriopods from Vinton, Ohio. Ohio Naturalist 2(3): 187

Shelley, R.M. 1977. The milliped genus Croatania (Polydesmida: Xystodesmidae). Proceedings of the Biological Society of Washington 90:302-325.

1978. Millipeds of the eastern Piedmont region of North Carolina, U.S.A. (Diplopoda). Journal of Natural History 12:37-79.

1980. Revision of the milliped genus Pleuroloma (Polydesmida: Xystodesmidae). Canadian Journal of Zoology 58:129-168.

. 1986. The genera of the tribe Apheloriini. Pages 205-211 in R.M. Shelley and D.R. Whitehead, editors, A reconsideration of the milliped genus Sigmoria, with a revision of Deltotaria and an analysis of the genera in the tribe Apheloriini (Polydesmida: Xystodesmidae). Memoirs of the American Entomological Society No. 35:1-223.

. 1988. The millipeds of eastern Canada (Arthropoda: Diplopoda). Canadian Journal of Zoology 66: 1638-1663.

1993. Revision of the milliped genus Scytonotus Koch (Polydesmida: Polydesmidae). Brimleyana 19:160 .

. 1994. The Chonaphini, a biogeographically significant milliped tribe in eastern and western North America (Polydesmida: Xystodesmidae). Brimleyana 20:111-200.

1997. A re-evaluation of the milliped genus Motyxia Chamberlin, with a re-diagnosis of the tribe Xystocheirini and remarks on the bioluminescence (Polydesmida: Xystodesmidae). Insecta Mundi 11(3-4):331-351.

2000. Annotated checklist of the millipeds of North Carolina (Arthropoda: Diplopoda), with remarks on the genus Sigmoria Chamberlin (Polydesmida: Xystodesmidae). Journal of the Elisha Mitchell Scientific Society 116(3):177-205.

2002. The milliped genus Oriulus Chamberlin (Julida: Parajulidae). Canadian Journal of Zoology 80:100-109.

Shelley, R.M., C.T. McAllister, and M.F. Medrano. 2006. Distribution of the milliped genus Narceus Rafinesque, 1820 (Spirobolida: Spirobolidae). Western North American Naturalist 66:374-389.

Shelley, R.M., C.T. MCAllister, And Z.D. Ramsey. 2005. Discovery of the milliped Scytonotus granulatus (Say, 1821) in Oklahoma and Alabama, with a review of its distribution (Polydesmida: Xystodesmidae). Western North American Naturalist 65:112-117.

Shelley, R.M., C.T. MCAllister, AND S.B. SMith. 2004. Discovery of the milliped Pleuroloma flavipes (Polydesmida: Xystodesmidae) in Texas, and other records from west of the Mississippi River. Entomological News 114:2-6.

SNIDER, R.M. 1991. Updated species lists and distribution records for the Diplopoda and Chilopoda of Michigan. Michigan Academician 24:177-194.

Whitehead, D.R., AND R.M. Shelley. 1992. Mimicry among aposematic Appalachian xystodesmid millipeds (Polydesmida: Chelodesmidea). Proceedings of the Entomological Society of Washington 94:177-188. 
Williams, S.R., and R.A. Hefner. 1928. The millipedes and centipedes of Ohio. Ohio State University Bulletin 33(7) [Ohio Biological Survey Bulletin 18]:91146.

Wood, H.C. 1864. Descriptions of new species of North American Polydesmidae. Proceedings of the Academy of Natural Sciences of Philadelphia 16:6-10.

1865. The Myriapoda of North America. Transactions of the American Philosophical Society 13: $137-248$
WraY, D.L. 1967. Insects of North Carolina. 3rd supplement. North Carolina Department of Agriculture, Division of Entomology, Raleigh. 181 pp.

Received 8 May 2006 Accepted 15 September 2006 